\title{
SIKAP SISWA TERHADAP PELAJARAN FISIKA DI SMAN KABUPATEN BATANGHARI
}

\author{
Astalini $^{1)}$, Dwi Agus Kurniawan ${ }^{2)}$, Sumaryanti ${ }^{3)}$ \\ 1) Program Studi Pendidikan Fisika Fakultas Keguruan dan Ilmu Pendidikan, Universitas Jambi, Jambi, Indonesia \\ E-mail: astalinizakir@unja.ac.id \\ 2) Program Studi Pendidikan Fisika Fakultas Keguruan dan Ilmu Pendidikan, Universitas Jambi, Jambi, Indonesia \\ E-mail:Dwiagus.k@unja.ac.id \\ 3) Program Studi Pendidikan Fisika Fakultas Keguruan dan Ilmu Pendidikan, Universitas Jambi, Jambi, Indonesia \\ E-mail: Sumaryantishm@gmail.com
}

\begin{abstract}
Abstrak. Penelitian ini bertujuan untuk mengetahui sikap serta kendala atau masalah yang dihadapi siswa terhadap mata pelajaran fisika di SMA Kabupaten Batanghari. Jenis penelitian ini yaitu kualitatif kuantitatif menggunakan prosedur penelitian survei dengan instrumen yang digunakan adalah angket dan wawancara. Subjek dari penelitian ini yaitu 926 siswa di lima SMA Kabupaten Batanghari. Teknik analisis data kuantitatif menggunakan descriptive statistic sedangkan untuk data kualitatif menggunakan teknik analisis data model Miles dan Huberman. Hasil dari 4 indikator yang didiskusikan pada penelitian ini, pada Indikator implikasi sosial terhadap fisika sebanyak $54.3 \%$ berkategori baik. Untuk indikator adopsi dari sikap ilmiah sebesar $61.2 \%$ berkategori baik. Kemudian pada indikator kesenangan dalam belajar fisika sebesar $55.5 \%$ berkategori cukup. Sedangkan pada indikator ketertarikan berkarir dibidang fisika sebanyak $57.9 \%$ siswa berkategori cukup.
\end{abstract}

Kata Kunci: Sikap; Sikap ilmiah; Fisika

\section{PENDAHULUAN}

Pendidikan pada dasarnya adalah usaha sadar untuk menumbuhkembangkan potensi sumber daya manusia terutama peserta didik yang dilakukan dengan cara membimbing dan memfasilitasi kegiatan belajar mereka. Salah satu jenjang pendidikan yang memperoleh sumber daya manusia yang berkualitas dan memiliki daya saing tinggi yaitu SMA [1]. Siswa SMA memiliki daya pikir yang sedang berkembang dan semangat keingintahuan yang tinggi dalam menuntut ilmu. Maka dari itu salah satu mata pelajaran yang dapat menunjang potensi siswa dan wajib diajarkan di SMA yaitu fisika. Fisika merupakan pelajaran yang menjelaskan pengetahuan tentang alam semesta yang membutuhkan kemampuan untuk terus dilatih agar dapat bertambah daya pikir dan kemampuan nalar [2]. Meski demikian, tidak semua siswa dapat mempelajari konsep fisika dengan baik.

Fisika pada kenyataannya menjadi salah satu mata pelajaran yang dianggap berat dan dihindari oleh sebagian peserta didik karena membutuhkan ketekunan, keseriusan dan banyak latihan [3][4]. Fisika masih dianggap sulit bagi siswa terutama karena pembelajaran berlangsung secara konvensional dimana siswa diharuskan menghafalkan rumus-rumus yang abstrak [5]. Minat belajar fisika siswa yang rendah menyebabkan siswa malas mengerjakan tugas, kurang suka membaca buku atau halhal yang berkenaan dengan fisika, dan merasa senang bila tidak belajar fisika karena guru tidak hadir. Hal ini akan mengganggu proses belajar siswa dan membuat tujuan pembelajaran tidak tercapai. Akibatnya, kualitas pendidikan menurun karena rendahnya hasil belajar siswa. Untuk itu perlu diadakan penilaian terhadap aspek belajar siswa.

Selain kognitif dan psikomotorik, penilaian afektif juga sangat penting sebagai alat ukur untuk melihat minat belajar siswa terhadap fisika melalui sikapnya. Sikap siswa berperan penting dalam pelatihan sistematis dan ilmiahnya [6]. Sikap merupakan hal pertama yang dilihat dari peserta didik apabila menyukai pelajaran fisika atau tidak. Sikap positif akan membuat siswa berkelakuan baik dan menyelesaikan akademiknya dengan baik [7]. sebaliknya, apabila siswa bersikap negatif maka akan cenderung menjauhi, membenci dan menghindari sesuatu. Penilaian sikap dinilai secara tidak langsung dan berkelanjutan pada semua subjek berdasarkan sikap positif dan negatif selama bersekolah di dalam dan di luar pembelajaran, menggunakan lembar observasi atau jurnal [8]. Sikap siswa terhadap fisika yang akan didiskusikan pada fokus penelitian ini berhubungan dengan beberapa indikator diantaranya indikator implikasi sosial terhadap fisika, adopsi 
dari sikap ilmiah, kesenangan belajar fisika dan ketertarikan memperbanyak waktu untuk belajar fisika.

Implikasi sosial dari fisika memperlihatkan bagaimana pengaruh atau dampak dari ilmu fisika dalam kehidupan sosial. Banyak manfaat-manfaat sosial yang diperoleh sebagai akibat perkembangan sains dan teknologi. Dalam pembelajaran disekolah, baik didalam kelas maupun di lab, implikasi sosial dari fisika dapat dilihat dari bagaimana kerja sama dan kemandirian siswa dalam kelompok. Siswa dapat aktif dan termotivasi selama proses pembelajaran apabila dituntut untuk dapat berbagi informasi, kerjasama dalam kelompok dan menghargai orang lain [9]. kemampuan sosial siswa akan lebih menonjol Saat bekerja sama dibandingkan bekerja sendiri [10]. Bentuk kemandirian siswa juga dapat dilihat dari pengerjaan tugas atau PR yang diberikan oleh guru serta bagaimana siswa tidak bergantung pada orang lain dan meyakini kemampuannya sendiri.

Adopsi dari sikap ilmiah memuat tentang sikap-sikap ilmiah yang perlu diterapkan dalam mempelajari fisika. Sikap ilmiah diartikan sebagai kecenderungan, kesiapan, kesediaan seseorang untuk memberikan tanggapan secara ilmu pengetahuan dan memenuhi syarat (hukum) ilmu pengetahuan yang telah diakui kebenarannya [11]. Sikap ilmiah memiliki 3 komponen utama yaitu keyakinan, perasaan dan tindakan [12]. Dari tiga komponen tersebut dapat diterapkan penggunaan cara atau metode ilmiah yang dapat membentuk sikap aktif, mandiri, pola pikir kritis, logis dan terstruktur. Misalnya ketika melakukan eksprimen, siswa harus mencari informasi lebih ilmiah melalui langkah-langkah percobaan yang terstruktur dan jelas. Dengan begitu, pengetahuan yang didapat akan lebih terkonsep yang hasilnya membuktikan kebenaran dari hipotesis percobaan yang diteliti siswa.

Kesenangan dalam belajar fisika adalah rasa suka siswa untuk mempelajari fisika yang dijunjung oleh keingintahuan yang tinggi. Ilmu fisika akan mudah diterima apabila sikap siswa positif dalam melibatkan strtegi untuk menyelesaikan permasalahan didalamnya. [13], "kesenangan dalam pelajaran fisika yaitu jika para siswa tahu bagaimana merencanakan dan menerapkan strategi solusi untuk pertanyaan melalui metode pengajaran". Selain metode, faktor yang membuat siswa senang belajar yaitu ruang kelas. Ruang kelas yang nyaman dapat mengembangkan keterampilan siswa dan meningkatkan kesenangan belajar fisika [14]. Suasana yang diciptakan oleh ruang kelas yang nyaman membuat siswa fokus dan semangat dalam melakukan proses pembelajaran fisika.

Ketertarikan dalam memperbanyak waktu belajar fisika dapat diartikan sebagai ungkapan kesukaan siswa dalam mempelajari fisika sehingga mempergunakan waktu luang untuk mempelajari fisika lebih dalam. Sikap siswa terhadap pembelajaran sains mengacu pada perasaan senang atau ketertarikan peserta dalam belajar sains [15]. Siswa akan lebih tertarik melakukan eksperimen dirumah, ke perpustakaan, atau membaca buku maupun jurnal tentang fisika yang meningkatkan pengetahuannya. Selain itu, pembelajaran fisika akan terasa senang ketika siswa memiliki karakter yang lebih intensif [16]. Karena siswa lebih sering meluangkan waktu untuk belajar fisika dengan rutin membuatnya fokus dan memahami konsep. Dengan banyaknya waktu untuk belajar fisika maka akan berdampak baik pada prestasi dan hasil belajar siswa.

Berdasarkan hasil observasi awal, Siswa SMA di kabupaten Batanghari masih banyak yang kurang tertarik mempelajari fisika karena memandang fisika itu sulit. Hal tersebut menarik perhatian peneliti untuk menelusuri lebih dalam mengenai sikap siswa berdasarkan indikator. Terdapat diantaranya beberapa indikator sikap siswa yang dikembangkan oleh Rio Darmawangsa (2018) yaitu implikasi sosial belajar fisika, adopsi dari sikap ilmiah, Kesenangan dalam belajar fisika dan Ketertarikan dalam memperbanyak waktu belajar fisika. Berdasarkan penelitian yang akan dilakukan, yang menjadi pertanyaan dalam penelitian ini adalah:

1. Bagaimana caranya mendeskripsikan sikap siswa dengan menggunakan indikator dalam pembelajaran fisika?

2. Kendala apa saja yang dihadapi didalam meningkatkan sikap pada saat pembelajaran fisika?

3. Bagaimana cara meningkatkan sikap dalam pembelajaran fisika?

Melalui temuan atau hasil penelitian ini, diharapkan dapat membantu berkontribusi/membantu guru fisika dalam mendesain pembelajaran agar dapat meningkatkan sikap siswa terhadap fisika secara efektif.

\section{METODE PENELITIAN}

\section{A. Jenis Penelitian}

Penelitian ini menggunakan jenis kualitatif kuantitatif menggunakan prosedur penelitian survei. Rancangan penelitian survei adalah prosedur penelitian kuantitatif dimana peneliti mengadministrasikan survei pada sampel atau pada seluruh populasi orang untuk mendeskripsikan sikap, pendapat, perilaku, atau ciri khusus populasi [17]. Wawancara dilakukan untuk memperkuat hasil angket yang diberikan pada siswa. tujuan dari penerapan desain pada penelitian ini untuk mengetahui gambaran sikap siswa terhadap pelajaran fisika di SMA Kabupaten Batanghari.

\section{B. Subjek Penelitian}

Subjek penelitian ini adalah 926 siswa dari 5 sekolah SMA di Kabupaten Batanghari. Teknik pengambilan sampelnya adalah Total sampling. Subjek yang diambil adalah kelas X, XI, dan XII dari jurusan MIPA yang terdiri dari 573 perempuan dan 353 laki-laki .

\section{Instrumen penelitian}

Instrumen dalam penelitian ini menggunakan angket yang diadopsi dari penelitian Rio Darmawangsa (2018). Ada 54 item pernyataan yang valid pada instrumen ini menggunakan skala likert. Skala tersebut terdiri dari 5 point dengan nilai sangat setuju adalah 5 , setuju yaitu 4 , netral yaitu 3 , tidak setuju yaitu 2, dan sangat tidak setuju adalah 1. Setiap pernyataan merupakan perwakilan dari tiap Indikator sikap. Fokus penelitian ini pada 4 dimensi sikap yaitu implikasi sosial dari fisika, adopsi dari sikap ilmiah, kesenangan belajar fisika, dan ketertarikan dalam memperbanyak waktu belajar fisika. Pengumpulan data juga melalui wawancara untuk memperoleh pendapat siswa mengenai alasan siswa bersikap terhadap 
pembelajaran fisika. Pedoman wawancara dibuat berdasarkan indikator-indikator sikap yang digunakan pada angket.

\section{Prosedur penelitian}

Penelitian dimulai dengan mengikuti prosedur secara bertahap. Pada Tahap persiapan, proposal dibuat, merumuskan masalah dan variabelnya. Kemudian dilakukan peninjauan pustaka, mencari teori pendukung dan memperdalam bahasan masalah yang diteliti agar diperoleh gambaran penelitian yang akan dilakukan serta instrumen yang dibutuhkan. Pada tahap pengambilan data, kuisioner diberikan kepada 926 siswa di lima SMA Kabupaten Batanghari. Siswa yang diwawancarai sejumlah 30 orang. Dari data tersebut kemudian dilakukan analisis data yaitu pengkodean data, penyaringan data-data yang layak dan analisis dari data tersebut.

\section{E. Teknik analisis data}

Untuk menggambarkan data berupa sikap siswa, maka statistik yang digunakan adalah statistik deskriptif. Suatu gambaran atau penyajian data dalam jumlah besar yang mencakup mean, modus, median, maksimum, minimum, dan standar deviasi merupakan statistik deskriptif [18]. Data dianalisis menggunakan Program SPSS 24 untuk memperoleh presentase, frekuensi, rata-rata dan standar deviasi data. Data kualitatif dari hasil wawancara dianalisis konten menggunakan model Miles dan Huberman.

\section{HASIL DAN PEMBAHASAN}

Adapun hasil penelitian dan pembahasan dari keempat indikator tersebut adalah sebagai berikut.

\section{A. Implikasi Sosial dari Fisika}

Hasil pengolahan data implikasi sosial siswa SMA terhadap fisika dapat dideskripsikan oleh tabel berikut :

TABEL 1

STATISTIK DESKRIPTIF IMPLIKASI SOSIAL DARI FISIKA SMAN KABUPATEN BATANGHARI

\begin{tabular}{lc}
\hline Mean & 18,34 \\
\hline Modus & 27 \\
\hline Median & 18 \\
\hline Skor Mininum & 8 \\
\hline Skor Maksimum & 25 \\
\hline Standar Deviasi & 2,85515 \\
\hline
\end{tabular}

TABEL 2

KLASIFIKASI IMPLIKASI SOSIAL DARI FISIKA SMAN KABUPATEN BATANGHARI

\begin{tabular}{cccc}
\hline Rentang & Klasifikasi Sikap & Jumlah & Presentase \\
\hline $25-21$ & Sangat Baik & 213 & $23 \%$ \\
\hline $20-17$ & Baik & 475 & $51.3 \%$ \\
\hline $16-13$ & Cukup & 218 & $23.5 \%$ \\
\hline $12-9$ & Tidak Baik & 19 & $2.1 \%$ \\
\hline $8-5$ & Sangat Tidak Baik & 1 & $0.1 \%$ \\
\hline
\end{tabular}

Pada tabel 1 dan 2, respon siswa berkategori baik sebanyak $54.3 \%$ dengan skor maksimal dari keseluruhan pernyataan di indikator 1 adalah 25. Ini berarti siswa merasakan adanya implikasi fisika dalam kehidupan sosialnya. Sebanyak $23.5 \%$ siswa berkategori cukup menggambarkan siswa yang masih bingung mengenai adanya peran ilmu fisika dalam kemajuan teknologi. Sedangkan 2.2\% siswa berkategori tidak baik hal ini menunjukkan siswa tidak mengerti tentang adanya implikasi yang baik pada kehidupan sosial mereka.

Hasil analisis angket pada tabel 1 dengan indikator implikasi sosial dari fisika di SMA Kabupaten Batanghari, memperlihatkan dominan siswa berkategori baik. Adapun hasil wawancara terhadap beberapa siswa sebagai berikut,

Pertanyaan: Menurut anda, apakah fisika merupakan pelajaran yang sulit? Dan apa manfaatnya mempelajari fisika dalam kesharian anda?jelaskan!

Jawaban: Ya, sulit sekali. karena harus menghapal banyak rumus. Namun manfaatnya bisa dibilang banyak. seperti melempar bola basket ke ring, ngukur kecepatannya dll juga aplikasi fisika. Trus kalau manfaat dalam kehidupan seperti pada teknologi kendaraan atau listrik, banyak memakai konsep fisika.

Konsep dan prinsip-prinsip fisika banyak diaplikasikan pada kehidupan dan berkontribusi banyak dalam pengembangan dan kehidupan di era ini [19][20]. Maka dari itu, sebaiknya konsep fisika juga dikaitkan dalam kehidupan sehari-hari agar siswa tidak sulit membayangkan konsep yang abstrak kedalam kenyataannya. Konsep memiliki peran yang penting dalam pembelajaran sebagai pondasi dalam mempelajari fenomena alam [21]

\section{B. Adopsi dari sikap ilmiah}

Hasil pengolahan data nilai adopsi dari sikap ilmiah adalah dilihat pada tabel dibawah ini.

TABEL 3

STATISTIK DESKRIPTIF ADOPSI DARI SIKAP ILMIAH SMAN KABUPATEN BATANGHARI

\begin{tabular}{lc}
\hline Mean & 25,7019 \\
\hline Modus & 27 \\
\hline Median & 26 \\
\hline Skor Mininum & 16 \\
\hline Skor Maksimum & 35 \\
\hline Standar Deviasi & 3,30597 \\
\hline
\end{tabular}

TABEL 4

KLASIFIKASI ADOPSI DARI SIKAP ILMIAH DI SMAN KABUPATEN BATANGHARI

\begin{tabular}{cccc}
\hline Rentang & $\begin{array}{c}\text { Klasifikasi } \\
\text { Sikap }\end{array}$ & Jumlah & Presentase \\
\hline $35-29.4$ & Sangat Baik & 106 & $11.4 \%$ \\
\hline $29.3-23.8$ & Baik & 580 & $62.6 \%$ \\
\hline $23.7-18.2$ & Cukup & 235 & $25.4 \%$ \\
\hline $18.1-12.6$ & Tidak Baik & 5 & $0.5 \%$ \\
\hline $12.5-7$ & Sangat Tidak Baik & 0 & $0 \%$ \\
\hline
\end{tabular}

Pada tabel 3 dan 4, Adopsi dari sikap ilmiah siswa yang di kategorikan baik yaitu $61.2 \%$. Sikap kategori cukup terdapat $37.8 \%$ dan kategori sikap tidak baik yaitu $1.0 \%$. Adopsi dari 
sikap ilmiah lebih dominan sikap baik. dimana siswa rata-rata tidak terlalu menyukai pembelajaran fisika dibandingkan kategori lainnya. Adapun kategori baik mendominasi dalam hal ini yang berarti siswa dapat menerapkan sikap ilmiah ketika melakukan percobaan/eksperimen dalam mata pelajaran fisika.

Hasil analisis angket pada tabel 2 dengan indikator adopsi dari sikap ilmiah siswa di SMA Batanghari dominan menunjukkan sikap baik. Adapun hasil wawancara terhadap beberapa siswa sebagai berikut,

Pertanyaan : apakah anda suka mencari tau hal baru dan apa alasannya?

Jawaban : ya saya suka mencari tau hal baru yang belum saya ketahui karena itu menyenangkan dan membuat saya penasaran. Pikiran saya jadi lebih terbuka, Pengetahuan saya juga bertambah dengan informasi yang baru.

Berdasarkan hasil wawancara, Siswa lebih banyak memiliki pemikiran yang kritis dan ilmiah untuk mendapatkan informasi baru yang ia dapatkan. Selain itu juga ada rasa ingin tahu yang tinggi serta mau terbuka dan menerima pendapat orang lain. Siswa yang memiliki sikap ilmiah yang tinggi akan memiliki keingintahuan dan keinginan yang juga tinggi untuk menemukan dan menciptakan hal baru, terbuka, bekerjasama dalam tim, dan bertanggungjawab dengan tugas [22]. Kebiasaan siswa yang penasaran dengan hal-hal baru akan menimbul kan pertanyaan di pikiran siswa dan membuat mereka mencari tau tentang hal tersebut. Hal tersebut menunjukkan adanya interaksi signifikan antara sikap, kepercayaan dan kebiasaan [23]. Sikap sains akan mendorong kemauan siswa untuk mengajukan pertanyaan dalam pemikiran siswa dan meningkatkan semangat untuk menemukan jawaban permasalahan [12][24].

\section{Kesenangan dalam belajar fisika}

Hasil pengolahan data nilai Kesenangan dalam belajar fisika adalah dilihat pada tabel dibawah ini.

TABEL 5

STATISTIK DESKRIPTIF KESENANGAN DALAM BELAJAR FISIKA SMAN KABUPATEN BATANGHARI

\begin{tabular}{lc}
\hline Mean & 32.2 \\
\hline Modus & 31 \\
\hline Median & 32 \\
\hline Skor Mininum & 10 \\
\hline Skor Maksimum & 50 \\
\hline Standar Deviasi & 6.47 \\
\hline
\end{tabular}

TABEL 6

KLASIFIKASI KESENANGAN BELAJAR FISIKA DI SMAN KABUPATEN BATANGHARI

\begin{tabular}{cccc}
\hline Rentang & Klasifikasi Sikap & Jumlah & Presentase \\
\hline $50-42$ & Sangat Baik & 25 & $27.7 \%$ \\
\hline $41-34$ & Baik & 210 & $22.7 \%$ \\
\hline $33-26$ & Cukup & 514 & $55.5 \%$ \\
\hline $25-18$ & Tidak Baik & 156 & $16.8 \%$ \\
\hline $17-10$ & Sangat Tidak Baik & 21 & $2.3 \%$ \\
\hline
\end{tabular}

Jurnal Ilmu Pendidikan Fisika

Volume 3 Number 2 month September 2018. Page 59-64 p-ISSN: 2477-5959 e-ISSN: 2477-8451

Berdasarkan tabel 5 dan 6, menunjukkan bahwa kesenangan dalam belajar fisika berkategori baik sebanyak $25.4 \%$. Siswa berkategori cukup yaitu $55.5 \%$ dan siswa berkategori tidak baik sebanyak $19.1 \%$. Hasil ini menunjukkan rata-rata sikap siswa netral dalam belajar fisika, ada yang suka dan ada yang tidak terlalu menyukai belajar fisika.

Hasil analisis angket pada tabel 3 dengan indikator kesenangan dalam belajar fisika juga dominan berkategori baik. Hal ini didukung pula oleh hasil wawancara terhadap beberapa siswa sebagai berikut.

Pertanyaan: Apakah Anda senang belajar fisika? Apa alasannya!

Jawaban: iya. Saya cukup senang belajar fisika karena fisika itu sangat luas. Pelajarannya bisa ditemukan dikehidupan sehari-hari. Jadi saya berminat ingin mengetahui fenomena sebab akibatnya karena terdapat dialam walaupun kebanyakan rumus dan abstrak.

Berdasarkan hasil wawancara, siswa yang menyenangi pelajaran fisika menunjukkan adanya minat untuk belajar fisika. Kesenangan, perhatian, dan daya dorong setiap individu untuk belajar merupakan unsur pokok dalam pengertian minat [25]. Hal ini dikarenakan minat siswa akan ditunjukkan dalam sikapnya. Dampak besar sikap dan perilaku siswa dipengaruhi oleh minat, maka dari itu minat berperan penting dalam kehidupan siswa [26]. Siswa yang berminat terhadap kegiatan belajar fisika akan berusaha lebih keras dibandingkan siswa yang kurang berminat.

\section{Ketertarikan memperbanyak waktu belajar fisika}

Hasil pengolahan data nilai ketertarikan memperbanyak waktu belajar fisika adalah dilihat pada tabel dibawah ini.

TABEL 7

STATISTIK DESKRIPTIF KETERTARIKAN MEMPERBANYAK WAKTU BELAJAR FISIKA SMAN KABUPATEN BATANGHAR

\begin{tabular}{lc}
\hline Mean & 24.72 \\
\hline Modus & 25 \\
\hline Median & 25 \\
\hline Skor Mininum & 8 \\
\hline Skor Maksimum & 39 \\
\hline Standar Deviasi & 4.81 \\
\hline
\end{tabular}

TABEL 8

KLASIFIKASI KETERTARIKAN MEMPERBANYAK WAKTU BELAJAR FISIKA DI SMAN KABUPATEN BATANGHARI

\begin{tabular}{|cccc|}
\hline Rentang & Klasifikasi Sikap & Jumlah & Presentase \\
\hline $40-33.6$ & Sangat Baik & 36 & $3.9 \%$ \\
\hline $33.5-27.2$ & Baik & 204 & $22 \%$ \\
\hline $27.1-20.8$ & Cukup & 536 & $57.9 \%$ \\
\hline $20.7-14.4$ & Tidak Baik & 132 & $14.3 \%$ \\
\hline $14.3-8$ & Sangat Tidak Baik & 18 & $1.9 \%$ \\
\hline
\end{tabular}

Berdasarkan tabel 7 dan 8, sikap siswa berkategori baik dalam ketertarikan memperbanyak waktu belajar fisika yaitu $25.9 \%$. Siswa berkategori cukup sebesar $57.9 \%$. Sedangkan 
kategori tidak baik sebanyak $16.2 \%$. Keadaan ini menunjukkan bahwa siswa yang tertarik memperbanyak waktu belajarnya dalam mata pelajaran fisika tergolong banyak yang ditandai dengan mendominasinya kategori baik pada tabel tersebut.

Hasil analisis angket yang disajikan pada tabel 4 dengan indikator ketertarikan dalam memperbanyak waktu belajar fisika memiliki dominan kategori sikap baik. Adapun hasil wawancara sebagai berikut.

Pertanyaan: Ketika Anda pulang dari sekolah, apakah anda mempelajari kembali materi fisika di rumah?

Jawaban: iya, tetapi hanya kadang-kadang ketika saya merasa materi tersebut perlu dipelajari kembali.

Pertanyaan: lalu apakah ada materi yang tidak dipahami di sekolah bagaimana?

Jawaban: iya ada, jika saya tidak memahami materi disekolah maka saya akan pergi ke perpustakaan dan bertanya kepada guru atau teman ketika ketika ada jam kosong atau ketika jam istirahat.

Berdasarkan hasil wawancara pada siswa yang dikategorikan cukup diketahui bahwa ketika telah selesai sekolah siswa mempelajari fisika di rumah secara individu atau dalam kelompok dan bertanya kepada teman tentang materi yang belum dipahami. Siswa yang memiliki waktu luang dan tertarik untuk mengisinya dengan belajar fisika berarti memiliki rasa ingin tau dan penasaran untuk mempelajari fisika lebih dalam.hal tersebut merupakan sikap positif yang ditunjukkan siswa, namun berbeda dengan sikap negatifnya. Siswa yang memiliki sikap negatif atau kurang baik tidak akan meluangkan waktu belajarnya untuk mata pelajaran tersebut. Sikap ketertarikan siswa dalam menghabiskan waktu dalam fisika ini dapat membuat siswa serius untuk mempelajari fisika [27][28].

\section{E. Kendala}

Terdapat beberapa kendala yang dihadapi siswa ditiap indikator. Pada indikator implikasi sosial dari fisika, ada 20 responden atau 2.2\% dari 926 siswa yang berkategori sikap tidak baik. Kendala yang dihadapi siswa yaitu ketika proses pembelajaran berlangsung didalam kelas. Siswa seringkali sulit memaknai symbol kejadian dalam persamaan [29]. Siswa merasa fisika merupakan pelajaran yang sulit sehingga tidak bisa diterapkan dalam kehidupan sehari-hari. Maka dari itu kebanyakan siswa beranggapan bahwa fisika jauh dari kehidupan sosial dan sedikit manfaat yang bisa diambil darinya. Pada indikator adopsi dari sikap ilmiah $0.5 \%$ atau 5 orang siswa berkategori sikap tidak baik. Kendala yang dihadapi siswa seperti tidak berminat melakukan eksperimen atau percobaan karena ingin mendapat jawaban instan, terbuka dan mencari tau hal-hal baru akibat keingintahuan yang rendah.

Pada indikator kesenangan dalam belajar fisika ada $19.1 \%$ atau 177 orang yang berkategori sikap tidak baik. Demikian pada indikator ketertarikan memperbanyak waktu belajar fisika terdapat 150 orang atau $16.2 \%$ siswa yang berkategori sikap tidak baik. Kendala yang dihadapi pada dua indikator ini sama yaitu fisika masih sulit dicerna oleh daya fikir siswa. fisika berlandasan pada konsep sehingga yang dipelajari hal-hal abstrak yang membuat siswa kesulitan dalam memahami [30]. Pada pembelajaran fisika membutuhkan model dan metode belajar yang lebih menarik perhatian siswa agar belajar fisika lebih menyenangkan.

\section{KESIMPULAN}

Berdasarkan hasil analisis sikap siswa terhadap fisika di SMAN Kabupaten Batanghari, keempat indikator menunjukkan sikap siswa mendominasi kategori baik dan cukup. Indikator implikasi sosial dari fisika dan adopsi dari sikap ilmiah berkategori baik. Dapat dilihat kedua indikator ini memiliki hubungan yang linier. Siswa yang dilatih untuk menerapkan sikap ilmiah ketika proses pembelajaran dalam kelas maupun melakukan eksperimen atau percobaan seperti bekerjasama, aktif, berfikir logis serta kritis, maka kebiasaan bersikap ilmiah tersebut akan diaplikasikan dalam kehidupan sosialnya sehingga siswa merasakan manfaat dalam pelajaran fisika. Adapun indikator kesenangan dalam belajar fisika dan ketertarikan memperbanyak waktu belajar fisika juga memilki hubungan linier yang keduanya berkategori cukup. Siswa yang senang belajar fisika akan tertarik memperbanyak waktu untuk mendalami pelajaran fisika, mencari tahu pemecahan masalah fisika serta meningkatkan pengetahuan tentang fisika. Namun pada kenyataannya tidak banyak siswa yang menyukai fisika karena menganggap fisika itu sulit, sehingga kesukaan siswa terhadap fisika berkategori cukup. Fisika yang abstrak dan banyak menggunakan rumus menjadikan minat belajar siswa rendah sehingga siswa bersikap negatif. Akibatnya hasil belajar fisika siswa menurun. Diperlukan metode belajar yang lebih kreatif untuk menarik perhatian siswa seperti menggunakan media dalam proses belajar dan memperbanyak kegiatan eksperimen. Hal ini bertujuan agar siswa dapat mengaplikasikan ilmu fisika dalam kehidupan sehari-hari yang bisa meningkatkan minat dan hasil belajar fisika. Dengan ini membuat siswa memiliki sikap yang baik terhadap fisika.

\section{DAFTAR PUSTAKA}

[1] Hidayatulah, A.H., Yushardi, \& Sri Wahyuni. (2015) Pengembangan bahan ajar berbasis web interaktif dengan aplikasi e-learning moodle pada pokok bahasan besaran dan satuan di sma. Jurnal Pendidikan Fisika, 4(2), 110115.

[2] Hartuti, P.M. (2015). Peran konsep diri, minat dan kebiasaan belajar peserta didik terhadap prestasi belajar fisika. Jurnal Formatif , 5(2), 91-99.

[3] Sultan, A.D., \& Bancong, H. (2017). Pengaruh pendekatan multiple intelligences melalui model pembelajaran langsung terhadap sikap dan hasil belajar fisika peserta didik kelas XI IPA SMA Negeri 11 makassar. Jurnal Pendidikan Fisika Universitas Muhammadiyah Makassar, 5(1), 51-60.

[4] Rosdianto, H. (2017). Pengaruh Model Generative Learning Terhadap Hasil Belajar Ranah Kognitif Siswa Pada Materi Hukum Newton. JPFK (Jurnal Pendidikan Fisika dan Keilmuan, 3(2), 66-69.

[5] Rosdianto, H. (2017). Students' Conceptual Understanding through Generative Learning Model in 
Topic "Light". JPI (Jurnal Pendidikan Indonesia), 6(2), 259-262.

[6] Trivedi, R., \& Sharma, M.P. (2013). A study of students' attitude towards physics practicalat senior secondary level. International Journal of Scientific and Research Publications, 3(8), 1-4.

[7] Guido, R.M. (2013). Attitude and motivation towards learning physics. International Journal of Engineering Research \& Technology (IJERT), 2(11), 2087-2094.

[8] Putra, A., Masril, M., \& Yurnetti, Y. (2018). Planning model of physics learning in senior high school to develop problem solving creativitybased on national standard of education, IOP Conf. Series: Materials Science and Engineering 335, 1-12. doi:10.1088/1757899X/335/1/012073

[9] Yance, R.D., Ramli, E., \& Mufit, F. (2013). Pengaruh penerapan model project based learning (pbl) terhadap hasil belajar fisika siswa kelas xi ipa sma negeri 1 batipuh kabupaten tanah datar. Pillar Of Physics Education, 1(-), 48-54.

[10] Irwan, N., \& Sani, R.A. (2015). Efek model pembelajaran kooperatif tipe group investigation dan teamwork skills terhadap hasil belajar fisika. Jurnal Pendidikan Fisika, 4(1), 41-48.

[11] Damanik, D.P., \& Bukit, N. (2013). Analisis kemampuan berfikir kritis dan sikap ilmiah pada pembelajaran fisika menggunakan model pembelajaran inquiry Training (IT) dan Direct Instruction (DI). Jurnal Online Pendidikan Fisika, 2(1), 16-25.

[12] Mukhopadhyay, R. (2014). Scientific attitude-some psychometric considerations. IOSR Journal Of Humanities And Social Science (IOSR-JHSS) OSR-JHSS, 19, 98-100.

[13] Guido, R.M.D. (2018). Attitude And Motivation Towards Learning Physics. Arxiv Preprint Arxiv: 1805.02293

[14] Maharaj-Sharma, R., \& Sharma, A. (2017). Using Ict In Secondary School Science Teaching-What Students And Teachers In Trinidad And Tobago Say? European Journal Of Education Studies.

[15] Esther Agunbiade, K. N. (2017). An Exploratory Study of the Relationship between Learners' Attitudes Towards Learning Science and Characteristics of an Afterschool Science Club. African Journal of Research in Mathematics, Science and Technology Education, 271281.

[16] Manasia, L. (2015). Enjoyment Of Learning In Upper Secondary Education. An Exploratory Research. Procedia-Social And Behavioral Sciences, 180, 639-646.

[17] Creswell, J.W. (2012). Educational research: planning, conducting, and evaluating quantitative and qualitative research-4th ed. Boston: Edwards Brothers, Inc.

[18] Cohen, L., Manion, L., \& Morrison, K. (2005). Research methods In education. Routledge.

[19] Veloo, A., Nor, R., \& Khalid, R. (2015). Attitude towards physics and additional mathematics achievement towards physics achievement. International Education Studies, 8(3), 35-43.
[20] Rosdianto, H., \& Toifur, M. (2017). Implementasi Teori Distribusi Probabilitas Gaussian pada Kualitas Rangkaian Penyearah Gelombang Penuh. Spektra: Jurnal Fisika dan Aplikasinya, 2(1), 83-90.

[21] Kaniawati, A., Samsudin, Hasopa, Y., Sutrisno, A.D., \& Suhendi, E. (2016). The influence of using momentum and impulse computer simulation to senior high school students' Concept Mastery. Journal of Physics : Conference Series739 (2016) 012060

[22] Anisa, D.N., Masykuri, M., \& Yamtinah, S. (2013). Pengaruh model pembelajaran poe (predict, observe, and explanation) dan sikap ilmiah terhadap prestasi belajar siswa pada materi asam, basa dan garam kelas VII semester 1 SMP N 1 Jaten tahun pelajaran 2012/2013. Jurnal Pendidikan Kimia (JPK), 2(2), 16-23.

[23] Erdogan, S.C. (2017). Science teaching attitudes and scientific attitudes of pre-service teachers of gifted students. Journal of Education and Practice,8(6), 164170.

[24] Rosdianto, H. (2017). Penentuan Percepatan Gravitasi pada Percobaan Gerak Jatuh Bebas dengan Memanfaatkan Rangkaian Relai. Spektra: Jurnal Fisika dan Aplikasinya, 2(2), 107-112.

[25] Supardi, U.S., Leonard, Suhendri, H., \& Rismurdiyati. (2015). Pengaruh media pembelajaran dan minat belajar terhadap hasil belajar fisika. Jurnal Formatif, 2(1), 71-81.

[26] Riwahyudin, A. (2015). Sikap Siswa dan Minat Belajar Siswa terhadap Hasil Belajar IPA Siswa Kelas V Sekolah Dasar di Kabupaten Lamandau. Jurnal Pendidikan Dasar, 6(1), 11-23.

[27] Hartinah, Sitti., D. S., \& Setiawan, T. (2013). Leadership Teachers Attituded to Mathematical Learning. Jurnal Ilmu Pendidikan, 19(1).

[28] Rosdianto, H. (2018). Rancang Bangun Alat Praktikum Gerak Jatuh Bebas dengan Stopwatch Otomatis Sederhana. JIPF (Jurnal Ilmu Pendidikan Fisika), 3(1), 20-23.

[29] Kabil, O. (2015). Phylosophy In Physics Education. Procedia-Social and Behavioral Sciences 197. Doi:10.1016/7.sbspro.2015.07.057 hal 675-679.

[30] Civelek, T., Ucar, E., \& Ustunel, H. (2014). Effects of a Haptic Augmented Simulation on K-12 Students'Achievement and their Attitudes towards Physics, Eurasia Journal of Mathematics, Science \& Technology Education, 10(6), 565-574. 